\title{
PIONEERS OF CANADIAN ANAESTHESIA
}

DR. WILLIAM WEBSTER

\author{
M. MinuCK, M.D. ${ }^{\circ}$
}

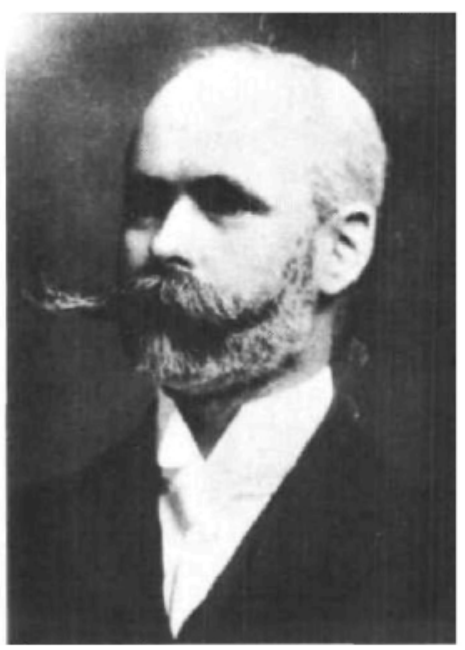

DR. WHLIAM Webster, D.s.o., v.M.

THE EARLX DEVELOPMENT OF ANAESTHESta in Manitoba, and probably in Western Canada, was due mainly to the single-handed efforts of the man whose biography follows. I deem it a special privilege to have been granted the opportunity to write this sketch. From the very beginning of his medical career Dr. Webster dedicated himself to the pursuit of scientific knowledge with particular emphasis on anaesthesia. Frequent refresher studies and application of current teaching methods characterized his life until the very end.

William Webster was born in Manchester, England in 1865. Educated as a teacher, he came to Manitoba at the age of 23 to teach in a small community called Snowflake, situated about 100 miles from Winnipeg. Soon after his arrival, he decided to become a doctor, and so, in 1891 he enrolled in the fledgling Manitoba Medical College (it had received its charter only seven years before) and graduated with distinction in 1895. After spending some years in general practice he went back to England for further studies in pathology and on his return to Winnipeg he continued in his general practice. It was during this period that he married Miss Jessie Gunn and fathered a daughter and two sons. During the next few years he developed such an interest in practicing anaesthesia that in 1905 he

'Head, Department of Anaesthesia, St. Boniface General Hospital; Associate Professor, Department of Anaesthesia, University of Manitoba. 
was given the position of Honorary Anaesthetist at the Winnipeg General Hospital and an appointment as Lecturer at the Manitoba Medical College.

As his concern with anaesthesia rose, his interest in general practice declined and in 1907 he became a full-time anaesthetist at the Winnipeg General Hospital, the first physician in Western Canada to limit his practice to this specialty. $\mathrm{He}$ held this position continuously until his death in 1934 with the exception of a leave of absence during World War I when he served as a Lieutenant Colonel overseas. In 1919 he was appointed Chief of Anaesthesia at the Winnipeg General Hospital and was given the rank of Associate Professor of Clinical Surgery in Anaesthesia at the University of Manitoba. When he was first appointed Lecturer at the Manitoba Medical College in 1905, he inaugurated the practice of supervised laboratory instruction for medical students and was one of the first teachers of anaesthesia to give practical instruction in anaesthesia to 4 th year medical students.

Under Dr. Webster's influence there was a steady growth of the specialty of anaesthesia in Manitoba; by his enthusiasm, precept and example, he stimulated others to practice anaesthesia on a full-time basis. Further, he raised the study of anaesthetic drugs and techniques to the scientific level by demonstrating its dependence for safety on sound basic physiological and pharmacological principles.

Dr. Webster participated in every aspect of medical endeavour. In 1897 he read a paper at the inaugural meeting of the Winnipeg Medical Society, and in 1922 be was elected President of the Canadian Society of Anaesthetists, a forerunner of the present Canadian Anaesthebists' Society. The distinct honour of this election can be appreciated fully only when one recalls how far, in time, Winnipeg was from larger Eastern centres in those years. Among his closest friends was Dr. E. I. McKesson. During a long and fruitful friendship, Dr. Webster bartered his laboratory and historical data for Dr. McKesson's mechanical expertise.

In 1924 Dr. Webster wrote the "Science and Art of Anaesthesia"1 which was not only the first textbook on anaesthesia by a Canadian but has remained so until very recent years. In addition, he published many scientific papers.

Dr. Webster's war career was no less brilliant than his medical career. The ambulance unit commanded by Webster took part in heavy engagements at Ypres, the Somme and Vimy Ridge. In January 1917, he was awarded the Distinguished Service Order and was also mentioned in despatches the same year. His other military awards included the Colonial Officer's Auxiliary Forces Decoration, the British War Medal and the Victory Medal. On his return to Winnipeg in 1918, he was given the post of Assistant Director of Medical Services.

As can be seen from his photograph, Dr. Webster was the owner af a fine mustache and beard, one which must be the envy of many of the readers of this biography. Some of the physicians still in practice recall the specially designed masks he had made to preserve the surgical cleanliness of the operating room without the need to sacrifice his magnificent adornment.

Dr. Webster's favourite hobby was working with motorized devices and he was one of the first to own a motor-car in Winnipeg, and soon after he added an outboard motor to his "stable". It was this latter pastime that led to the tragic accident that resulted in his death in 1934. 
In 1967, Dr. M. R. MacCharles of Winnipeg wrote about his good friend Dr. Webster as follows: ${ }^{2}$

One Saturday aftemoon he was starting the motor in his boat to go down the Red River and the motor took fire. The average individual probably would have thrown in a fire extinguisher and then would have withdrawn quickly; not Dr. Webster; he went down to the engine room and proceeded to put the fire out, which he did. In the process he inhaled so much of the fumes from the fire that he developed acute edema of the lungs and died that night. Dr. Webster was a classic example of a very fine gentleman.

Thus life came to an end abruptly for Dr. William Webster, D.S.O., V.M., at the age of 69 . From the time of his graduation in 1895 , he figured prominently as a major pioneer in the development of anaesthesia in Winnipeg and the West. Full-time anaesthesia began in these areas as a result of Dr. Webster's influence. It is interesting to note that after his death, while anaesthesiology flourished in other parts of the world, notably Eastem Canada and the United States, no major advance took place in Manitoba until the sixties. Dr. Webster was a dedicated man, and a "classic example of a very fine gentleman".2 Winnipeg was indeed fortunate that he selected it in which to spend his life.

I wish to acknowledge that the major source of my information was an article published by Dr. D.C. Aikenhead, ${ }^{3}$ a pupil and friend of Dr. Webster's. Dr. Aikenhead followed him as full-time head of the Department of Anaesthesia at the Winnipeg General Hospital until he retired in 1951. Another important source with particular respect to Dr. Webster's military career was Dr. M.R. MacCharles' "Letter to the Editor" of the Manitoba Medical Review." Finally I wish to ackowledge with thanks the secretarial assistance of Beverley Minuck.

Les débuts de la pratique de l'anesthésie au Manitoba et probablement dans toute la partie ouest du Canada sont dus en grande partie aux efforts de lhomme dont la biographie suit. C'est un grand privilège pour moi d'avoir l'occasion d'écrire ce mémoire. Depuis le tout début de sa carrière médicale, le docteur Webster s'est appliqué a la poursuite de la connaissance scientifique et, de façon plus spéciale, à l'anesthésie. De fréquents recyclages et lapplication des méthodes courantes d'enseignement ont caractérisé sa vie jusqu'aux derniers instants.

William Webster est né en 1865 à Manchester, Angleterre. Il est arrivé au Manitoba à lâge de 23 ans; comme il était préparé pour enseigner, il a travaillé dans une petite localité du nom de Snowflake, située à environ 100 milles de Winnipeg. Quelques temps après son arrivée, il décida de devenir médecin et, en 1891, il s'inscrivit à la débutante école de médecine du Manitoba (elle avait reçu sa charte seulement sept ans avant); il obtint son diplome avec distinction en 1895. Après quelques années de pratique générale, il retourna en Angleterre pour complèter ses études en pathologie; à son retour a Winnipeg, il continua a faire sa médecine générale. C'est à ce moment-là qu'il contracta mariage avec Mademoiselle Jessie Gunn; ils eurent une fille et deux fils. Au cours des quelques années suivantes, il a manifesté un tel intérêt à la pratique de l'anesthésie que, en 
1905, on lui donna le titre d'anesthésiste honoraire à l'hôpital General de Winnipeg et un poste de moniteur à l'école de médecine du Manitoba.

A mesure que croissait son intérêt pour l'anesthésie, son intérêt pour la pratique générale diminuait au point que, en 1907, il devint anesthésiste à temps complet à l'hôpital Général de Winnipeg; il a été le premier médecin de l'ouest canadien à consacrer tout son temps à cette spécialité. Il a conservé œe poste jusqu'à sa mort en 1934; il s'est absenté durant la première guerre alors qu'il a servi outremer à titre de lieutenant colonel. En 1919, il a été nommé chef du service d'anesthésie à lhôpital Général de Winnipeg et professeur agrégé de chirurgie clinique en anesthésie à l'université du Manitoba. En 1905, lorsqu'il a été nommé moniteur à l'école de médecine du Manitoba, il a inauguré la pratique de Penseignement en laboratoire pour les étudiants en médecine et il a étế un des premiers professeurs d'anesthésie à donner de l'enseignement clinique en anesthésie aux élèves de quatrième année de médecine.

A cause de son influence, l'anesthésie s'est développée de façon constante au Manitoba; son enthousiasme, son enseignement et son exemple ont éré des stimulants pour ses confrères et les ont incités à pratiquer l'anesthésie à temps complet. De plus, il a élevé l'étude des agents et des techniques anesthésiques à un niveau scientifique en démontrant que la sécurité de leur usage repose sur des principes de base de physiologie et de pharmacologie.

Le docteur Webster a participé, sous tous les angles, aux devoirs du médecin. En 1897, lors de l'assemblée inaugurale et la société médicale de Winnipeg, il présenta un travail; en 1922, il a été élu président de la Société Canadienne des Anesthésistes, le précurseur de la société actuelle. La mesure de lhonneur de cette élection ne peut s'évaluer que si lon se rappelle combien loin était Winnipeg, en ce temps-là, des centres de l'est.

Parmi ses amis les plus intimes, se trouvait le docteur E.I. McKesson. Durant cette longue et fructueuse amitié, le docteur Webster a accumulé des données historiques et de laboratoire pour lexpertise mécanique du docteur McKesson.

En 1924, le docteur Webster a écrit "la Science et l'Art de l'Anesthésie." Non seulement ce livre sur l'anesthésie était le premier écrit par un Canadien, mais il est demeuré le seul jusqu’à ces dernières années. Il a publié de plus, plusieurs articles scientifiques.

Sa carrière militaire n'a pas été moins brillante que sa carrière médicale. L'unité d'ambulance qu'il commandait a participé à de violentes rencontres à Ypres, sur la Somme et sur la Crête de Vimy. En janvier 1917, on lui décerna la médaille de lordre des Services Distingués, et, la même année, son nom était mentionné dans les dépêches. Ses autres décorations militaires sont: la Décoration des Officiers Coloniaux des Forces Auxilliaires, la Médaille de Guerre Britannique et la Medaille de la Victoire. En 1918, lors de son retour à Winnipeg, on lui confia le poste d'assistant directeur des services médicaux.

Comme le montre sa photographie, le Dr Webster portait une belle moustache et une belle barbe, de quoi rendre jaloux les lecteurs de cette biographie. Il y a des médecins qui pratiquent encore et qui se souviennent des masques spéciaux qu'il avait faits pour conserver la propreté de la chirurgie dans les salles d'opération sans qu'il soit nécessaire de sacrifier son stimulant idéal. 
Le passe-temps préféré du Dr Webster était de travailler sur les moteurs; à Winnipeg, il a été le premier propriétaire d'une voiture automobile; un peu plus tard, il ajoutait un moteur hors bord à son garage. C'est ce passe-temps favori qui entraîna le tragique accident et sa mort en 1934.

En 1967, son bon ami, le Dr M.R. MacCharles écrivat à son sujet: ${ }^{2}$ "Un samedi après-midi il partait son moteur pour descendre la rivière, et le moteur prit feu. La plupart des individus auraient probablement lancé un extincteur chimique et se seraient sauvé au plus tôt; ce n'est pas ce que fit le Dr Webster; il descendit dans la chambre à moteur et commença à éteindre le feu et il y réussit. En ce faisant, il inhala tellement de fumée qu'il développa un cedème pulmonaire aigu et mourut le soir même. Le Dr Webster était l'exemple classique du parfait gentilhomme."

C'est ainsi que prit fin brutalement la vie du Dr William Webster, D.S.O., V.M. à lầge de 69 ans. Depuis la date de sa graduation en 1895, il a été une figure dominante et un pionnier dans le progrès de l'anesthésie à Winnipeg et dans l'ouest. C'est grâce à l'influence du Dr Webster que des médecins, dans ces régions, se sont occupés à temps complet de l'anesthésie.

Il est intéressant de signaler que, après sa mort, alors que l'anesthésie progressait dans les autres parties du monde, notamment dans l'est du Canada et aux Etats-Unis, aucun progrès notable n'est survenu au Manitoba avant les années 60. Le Dr Webster était un homme dévoué et "lexemple classique du parfait gentilhomme". C'est bien heureux pour Winnipeg qu'il aie choisi cette ville pour y fixer son domicile.

Je tiens à signaler que j’ai puisé la plus grande partie de mes renseignements dans un article publié par le Dr Aikenhead, ${ }^{3}$ un élève et un ami du Dr Webster. Le Dr Aikenhead a succédé au Dr Webster comme chef à temps complet du dé. partement d'anesthésie de l'hôpital Cénéral de Winnipeg jusqu'à sa retraite en 1951. Une autre source importante de renseignements pour moi, concernant la carrière militaire du Dr Webster, a été un article du Dr MacCharles intitule: "Lettre à l'Editeur" de la revue médicale du Manitoba. Enfin, je tiens à exprimer ma gratitude à Beverley Minuck pour sa collaboration en qualité de secrétaire.

\section{REFERENCES}

1. Webster, Wruiam M.D. The Science and Art of Anaesthesia. C.V. Mosby Co., St. Louis (1924).

2. MacCharles, M.R. Letter to the Editor, Manitoba Med. Review, Vol. 47, \#6, p. 315 (June 1967).

3. ArkeNHEad, D.C. An Appreciation. Anesth. and Analg. 16: p. 312-317 (Nov.-Dec. 1937). 